\title{
PCR-ribotyping and pyrolysis mass spectrometry fingerprinting of environmental and hospital isolates of Clostridium difficile
}

\author{
N. M. AL-SAIF, G. L. O'NEILL, J. T. MAGEE, J. S. BRAZIER and B. I. DUERDEN \\ Department of Medical Microbiology and Public Health Laboratory, University of Wales College of Medicine \\ and PHLS Anaerobe Reference Unit, University Hospital of Wales, Cardiff CF4 $3 X W$
}

\begin{abstract}
The relationships between environmental isolates of Clostridium difficile were examined by two typing methods, PCR ribotyping and pyrolysis mass spectrometry (PyMS). The 184 isolates were divided into 23 different $P C R$ ribotypes, 13 of which were producers of toxins $A$ and $B$; the remaining 10 types did not produce either toxin $A$ or B. PyMS analysis resolved 31 groups with $60(32.5 \%)$ isolates in one group (group 9). In both methods most of the isolates showed similar clustering. PCR ribotypes of the environmental isolates were compared with those of clinical isolates that had been typed previously. Seventeen PCR types (13 toxigenic PCR types and four non-toxigenic types) were found in both sets of isolates.
\end{abstract}

\section{Introduction}

Clostridium difficile is the causative agent of pseudomembranous colitis (PMC) and most cases of antibiotic-associated diarrhoea $[1,2]$. Outbreaks of $C$. difficile cross-infection may occur in elderly hospitalised patients and in care facilities for the elderly. Several different typing schemes have been developed for $C$. difficile, including unmodified SDS-PAGE [3], SDS-PAGE of ${ }^{35} \mathrm{~S}$-methionine-labelled cultures [4], bacteriocin-bacteriophage typing [5], restriction endonuclease digest fragment length polymorphisms [6], serotyping [7], immunoblotting of outer-membrane proteins [8], antimicrobial resistance patterns [9], pyrolysis mass spectrometry (PyMS) $[10,11]$ and polymerase chain reaction (PCR) ribotyping of the intergenic space between the 16S and 23S rRNA genes of the ribosomal RNA gene complex $[12,13]$. Some of these methods are complex, expensive, limited to a few specialised laboratories, have poor discrimination and reproducibility, and may not type all strains of $C$. difficile.

PyMS typing for $C$. difficile has the advantage of rapid high throughput of strains with good discrimination. The system has the disadvantage that results cannot be compared from batch to batch and it does not assign a permanent type which can be useful in

Received 20 Jan. 1997; accepted 1 June 1997.

Corresponding author: Dr J. S. Brazier. the long-term epidemiological study of the species. PCR ribotyping is a new typing system which has been applied to various micro-organisms, and was first applied to $C$. difficile by Gurtler [12]. A modified method for routine typing of $C$. difficile was described recently [13]. This gives a permanent type designation for each strain, allowing results to be compared easily.

Recently a study examining the environment as a potential source of community-acquired human infections was conducted [14]. C. difficile was isolated from 184 of 2580 samples taken from farm animals, househeld pets, hospitals, family houses, student hostels, nursing homes for the elderly, soil and water. The majority $(75 \%)$ of environmental isolates produced toxins $\mathrm{A}$ and $\mathrm{B}$. To examine links between these 184 environmental isolates and clinical isolates from cases of PMC and AAD, the isolates were typed by PyMS and a modified PCR-ribotyping method.

\section{Materials and methods}

Bacterial strains

One hundred and eighty-four $C$. difficile isolates obtained from animals (cats, dogs, horses, pigeons, sheep) and from different environmental sites including soil, treated and untreated sources of water, hospital wards, family houses, nursing homes for the elderly and student hostels were examined [14]. The identity of the isolates was confirmed as described previously [15] and they were tested for the production of toxin $\mathrm{A}$ 
(entertoxin) and toxin B (cytotoxin) [15]. To compare the strains found in the general environment with those causing infection, $541 \mathrm{C}$. difficile isolates of clinical origin submitted to the Anaerobe Reference Unit (ARU; Cardiff) for the investigation of putative hospital outbreaks of AAD and PMC were included in the study. These isolates originated from hospitals throughout England and Wales.

\section{Pyrolysis mass spectrometry}

One colony was subcultured from each isolate on to Fastidious Anaerobe Agar (FAA; Lab M, Bury) and incubated anaerobically (Concept 300 Anaerobic Workstations; Fred Baker Scientific Ltd, Bradford) in an atmosphere of $\mathrm{N}_{2} 80 \%, \mathrm{CO}_{2} 10 \%, \mathrm{H}_{2} 10 \%$ for $48 \mathrm{~h}$ at $37^{\circ} \mathrm{C}$. The growth was sampled with a straight wire and transferred to each of four replicate pyrolysis foils which were heated to $100^{\circ} \mathrm{C}$ for $10 \mathrm{~min}$ to inactivate enzymes and dehydrate the specimen within $10 \mathrm{~min}$ of sampling. Foils were then stored in a vacuum desiccator before automated processing on a PMS 200X (Horizon Instruments, Heathfield, Sussex) pyrolysis mass spectrometer with pyrolysis for $4 \mathrm{~s}$ at $530^{\circ} \mathrm{C}$ and analysis of the pyrolysis products by mass spectrometry. Data were analysed as described previously [16].

\section{PCR ribotyping}

This was performed by the method of O'Neill et al. [13]. Single colony subcultures were grown anaerobically at $37^{\circ} \mathrm{C}$ for $24 \mathrm{~h}$ on FAA in an atmosphere of $\mathrm{N}_{2}$ $80 \%, \mathrm{CO}_{2} 10 \%, \mathrm{H}_{2} \quad 10 \%$. DNA was extracted from a suspension of 10-12 colonies in $100 \mu 1$ of Chelex 100 (BioRad Laboratories, Hercules, CA, USA) $5 \%$ by heating for $10 \mathrm{~min}$ at $100^{\circ} \mathrm{C}$ in a waterbath. PCR was performed with the primers P3 (5'-CTG GGG TGA AGT CGT AA CAA GG-3') and P4 (5'-GCG CCC TTT GTA GCT TGA CC-3'). Amplifications were performed in a final volume of $100 \mu \mathrm{l}$ with a reaction mixture containing $1.5 \mathrm{mM} \mathrm{MgCl}_{2}, 10 \mathrm{mM}$ Tris $\mathrm{HCl}$ (pH 9), $50 \mathrm{mM} \mathrm{KCl}$, Triton X-100 0.1\%, $2.5 \mathrm{U}$ of Taq polymerase (Promega, Madison, WI, USA), $200 \mu \mathrm{M}$ of each dNTP, $50 \mathrm{pmol}$ of each primer and $10 \mu \mathrm{l}$ of template DNA preparation.

Amplification consisted of 35 cycles of denaturation at $96^{\circ} \mathrm{C}$ for $1 \mathrm{~min}$, annealing at $56^{\circ} \mathrm{C}$ for $1 \mathrm{~min}$ and extension at $72^{\circ} \mathrm{C}$ for $2 \mathrm{~min}$. A negative control consisting of reaction buffer, primers, dNTPs, Taq polymerase and distilled water was included with each PCR run. The PCR products were separated electrophoretically on Metaphor Agarose (FMC BioProducts, Rockland, ME, USA) $3 \%$ at $150 \mathrm{~V}$ for $6 \mathrm{~h}$. DNA fragments were visualised by staining with ethidium bromide $0.5 \mathrm{mg} / \mathrm{L}$. Gels were photographed under UV illumination and the data were saved to floppy disc for analysis by the Gel Compar software (Applied Maths, Belgium). Isolates were compared by using the
Jaccard coefficient with band tolerance set at $2.5 \%$. Dendrograms were generated by unweighted pair group mean association (UPGMA). Isolates were assigned to different PCR types if they differed by a single band. Representative patterns of the different PCR ribotypes identified among 184 environmental isolates of $C$. difficile were examined three times to assess the reproducibility of the method.

\section{Results}

Results of PyMS fingerprinting of the environmental isolates showed one major group (group 9) comprising five subgroups containing $69(37 \%)$ of the 184 isolates. The remaining isolates were distributed among 30 other groups. Twenty-three distinct and reproducible banding patterns were found by PCR ribotyping. The number of bands per strain was in the range five to nine with an average of seven, in the size range 257-601 bp (Fig. 1). Thirteen PCR types were uniformly positive for toxins $\mathrm{A}$ and $\mathrm{B}$, and 10 were uniformly negative for both toxins (Fig. 2). The correlation between PCR ribotyping and PyMS fingerprints is shown in Fig. 3.

PCR type 1 was the largest cluster comprising 76 (41\%) of the 184 isolates. PCR type 1 contained 58 $(76.3 \%)$ of the hospital isolates demonstrating significant contamination of the hospital environment by this particular type. Eighteen other isolates belonging to PCR type 1 were found also in soil (1), water (7), animals (1), family houses (2), student hostels (3), and from nursing homes for the elderly (4). Fifteen further PCR-types each contained between two and 13 isolates, and the remaining seven PCR types each contained a single isolate. Some PCR types comprised mostly isolates from one source, e.g., types 2, 5 and 34 (water), type 9 (soil) and type 33 (veterinary clinic), whereas other PCR types containing more than one isolate contained isolates from several different sources. The 23 PCR ribotypes of environmental isolates were compared with the $64 \mathrm{PCR}$ ribotypes found in the library of 541 clinical isolates of $C$. difficile; 17 PCR ribotype patterns found in clinical strains matched those in environmental sources. There were six PCR ribotypes found only in environmental isolates and the remaining 41 PCR ribotypes were found only in clinical isolates.

\section{Discussion}

Several methods have been employed to characterise and distinguish between different strains of $C$. difficile. The majority of typing methods have been aimed at investigating putative common sources of outbreaks in cross-infection incidents in hospitals. However, typing schemes have so far contributed little to the overall understanding of the extra-nosocomial epidemiology 

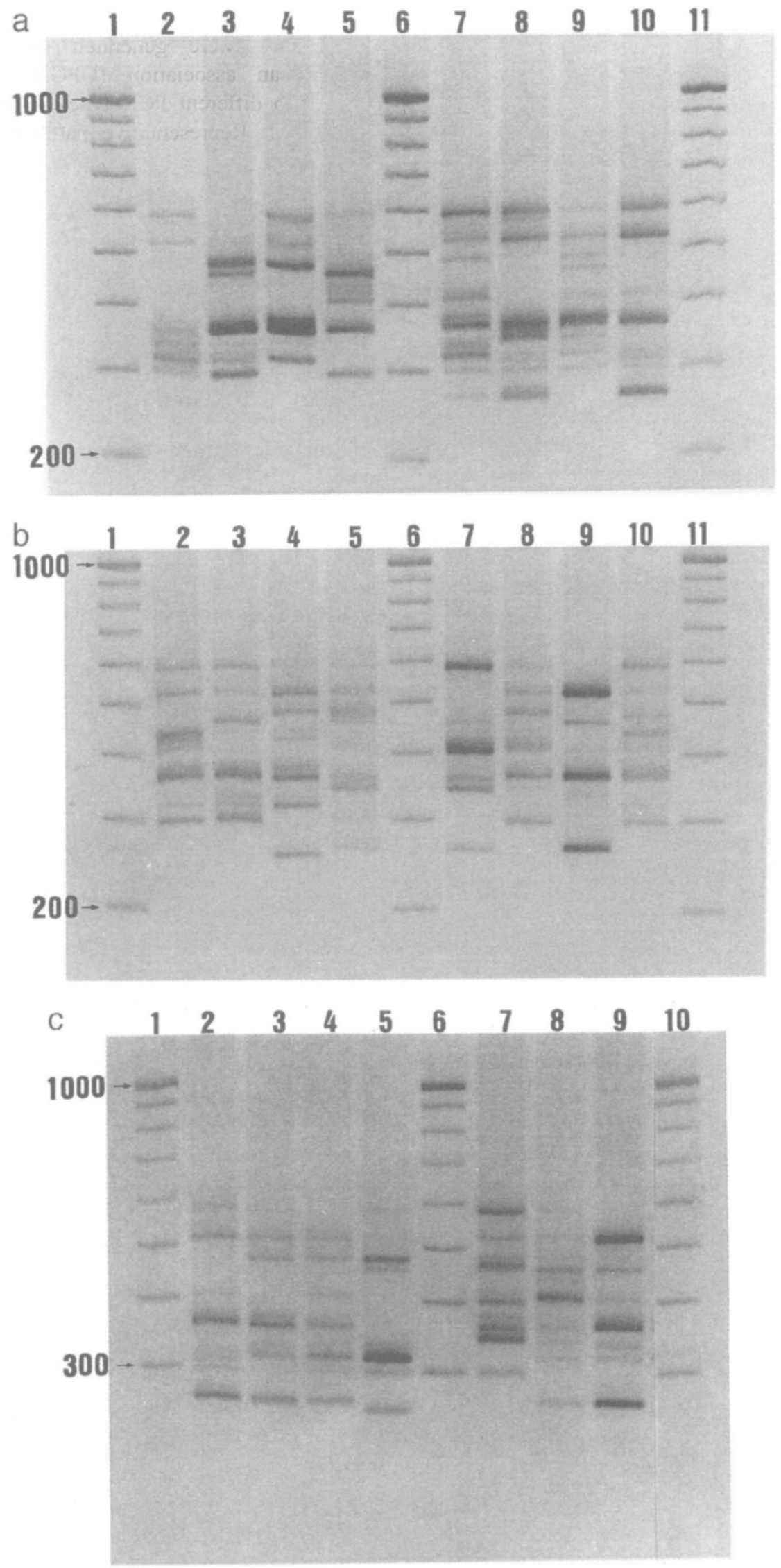

Fig. 1. Representative patterns of the different PCR ribotypes identified among 184 environmental isolates of $C$. difficile. (a) Lane 1, 100-bp size marker; 2, PCR type 6; 3, type 34; 4, type 2; 5, type 42; 6, 100-bp size marker; 7 , type $11 ; \mathbf{8}$, type $14 ; 9$, type $5 ; 10$, type $8 ; 11,100$-bp size marker. (b) Lane 1,100 -bp size marker; 2 , type $35 ; 3$, type $26 ; 4$, type $10 ; 5$, type $41 ; 6$, 100-bp size marker; 7 , type $40 ; 8$, type $9 ; 9$, type $38 ; 10$, type $30 ; 11$, 100-bp size marker. (c) Lane 1, 100-bp size marker; 2 , type $1 ; 3$, type $46 ; 4$, type $23 ; 5$, type $44 ; 6$, 100-bp size marker; 7, type 12; $\mathbf{8}$, type $39 ; 9$, type $33 ; 10,100$-bp size marker. 


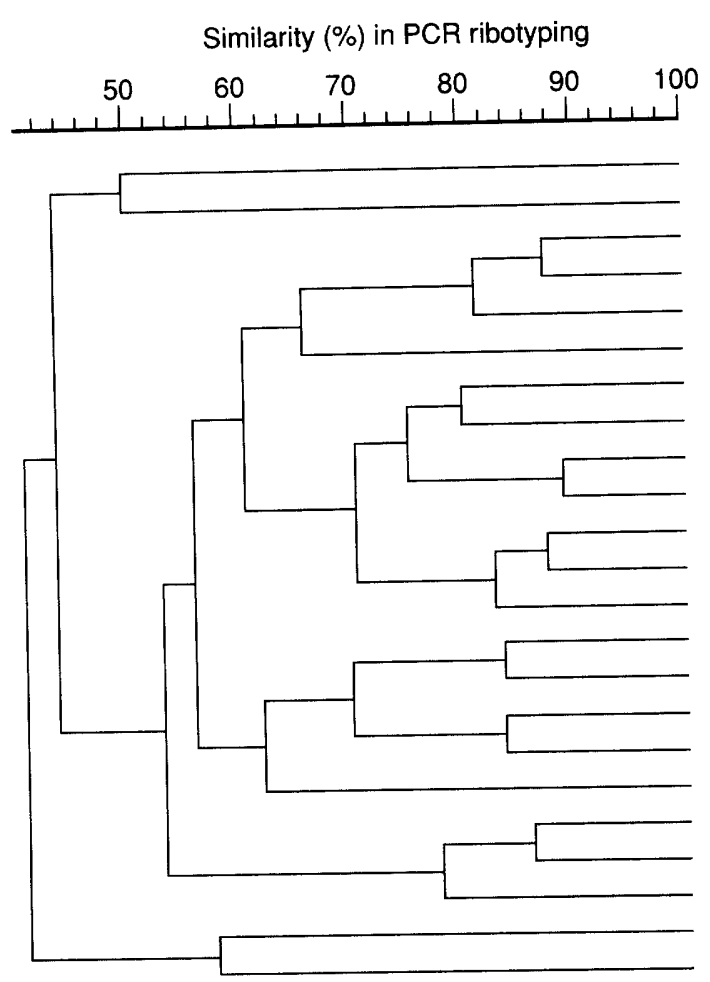

$\begin{array}{lccc}\begin{array}{l}\text { Typical } \\ \text { strain }\end{array} & \begin{array}{c}\text { PCR } \\ \text { type }\end{array} & \begin{array}{c}\text { Toxin } \\ \text { production } \\ \text { (toxin A \& B) }\end{array} & \begin{array}{c}\text { Number } \\ \text { of isolates }\end{array} \\ \text { Soil 16 } & 40 & - & 1 \\ \text { Soil 20 } & 42 & + & 1 \\ \text { Water 114 } & 11 & + & 1 \\ \text { Water 38 } & 08 & + & 11 \\ \text { L.H. 76 } & 23 & + & 7 \\ \text { Water 40 } & 35 & - & 1 \\ \text { Home 11 } & 39 & - & 2 \\ \text { Soil 19 } & 41 & - & 1 \\ \text { Water 20 } & 05 & - & 5 \\ \text { L.H. 14 } & 30 & - & 1 \\ \text { Water 41 } & 10 & + & 14 \\ \text { Dog 26 } & 12 & - & 13 \\ \text { Dog 13 } & 09 & - & 13 \\ \text { Water 139 } & 26 & + & 3 \\ \text { Pigeon 12 } & 02 & - & 6 \\ \text { Radish C } & 33 & + & 7 \\ \text { V. Clinic 15 } & 46 & - & 2 \\ \text { Home 05 } & 38 & + & 3 \\ \text { Water 19 } & 14 & + & 6 \\ \text { UHW 01* } & 06 & + & 1 \\ \text { CRI 28* } & 01 & + & 76 \\ \text { Water 30 } & 34 & + & 7 \\ \text { Potato A } & 44 & & 2\end{array}$

Fig. 2. PCR ribotyping of animal and environmental isolates. LH, Llandough Hospital; UHW, University Hospital of Wales; CRI, Cardiff Royal Infirmary.

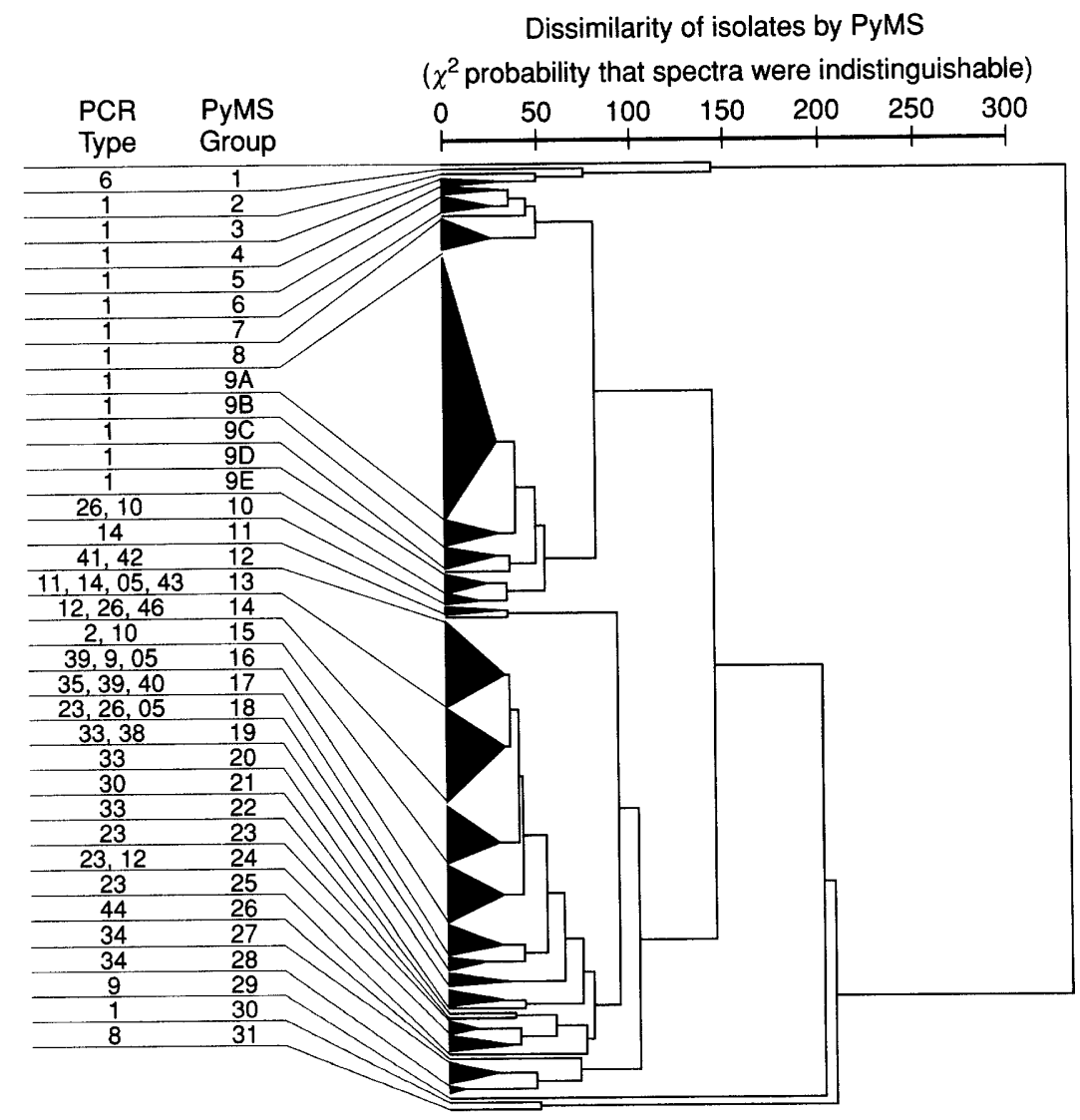

Fig. 3. Grouping of $C$. difficile isolates by PyMS and comparison with PCR-types. 
and ecology of $C$. difficile. In this study, PyMS was used to demonstrate the great diversity of strains obtained from a wide range of different environmental sites. There was a close relationship between the hospital environmental isolates, notably in PyMS group 9 , indicating the high prevalence of this type in the hospital environment. PCR ribotyping was used to allocate a definite type designation to each $C$. difficile isolate, allowing results to be compared easily. All isolates in PyMS group 9 corresponded to isolates belonging to PCR type 1. PyMS subdivided some PCRtypes, but broadly confirmed the PCR results. PCR ribotyping is a relatively new typing scheme which has been applied to a variety of organisms including Escherichia coli [17], Burkholderia cepacia [18] and Staphylococcus aureus [19].

Of the environmental isolates, $139(75.5 \%)$ produced toxins A and B and so were theoretically capable of inducing disease in susceptible patients. The isolates found in the hospital environment tended to be indistinguishable, e.g., PCR type 1. In many hospital settings there is often one endemic or even epidemic strain while in others a variety of strains may be responsible for outbreaks of $C$. difficile infection. The PCR ribotyping results were in agreement with this interpretation. With isolates from four hospitals in one district, $56(89 \%)$ of the 63 isolates from three hospitals (Cardiff Royal Infirmary, University Hospital of Wales and Caerphilly District Miner's Hospital) belonged to PCR type 1, whereas the 13 isolates from Llandough Hospital were divided into five PCR ribotypes with just two isolates belonging to PCR type 1. Isolates from other sources such as water or soil showed greater dissimilarity. Nosocomial acquisition of $C$. difficile is well documented, but it is not yet clear how $C$. difficile is acquired in the community. A link between environmental strains and clinical strains responsible for cases of $\mathrm{AAD}$ and $\mathrm{PMC}$ is suggested for some PCR types found in both the environmental sets and strains of clinical origin typed at the ARU in Cardiff. Of the 23 environmental PCR ribotypes, 17 were matched with similar PCR ribotypes found in clinical strains. However, there was greater diversity of PCR ribotypes and PyMS types among environmental strains than was found in routine typing of clinical isolates. The matching PCR ribotypes were from different animals and environmental sites indicating possibilities of environmental acquisition of $C$. difficile. This supports the findings of O'Neill et al. [20] who reported that apparent relapses of $C$. difficile infection were either re-infection with the same strain or another which may have been acquired from the environment. Overall, typing clearly showed that similar PCR-types are found in both clinical and environmental isolates in the UK demonstrating the potential importance of the environment as a source of $C$. difficile infection in man.

\section{References}

1. George WL, Sutter VL, Finegold SM. Antimicrobial agentinduced diarrhea - a bacterial disease. J Infect Dis 1977; 136: $822-828$.

2. George RH, Symonds JM, Dimock F et al. Identification of Clostridium difficile as a cause of pseudomembranous colitis. BMJ 1978; 1: 695 .

3. Delmee M, Laroche Y, Avesani V, Cornelis G. Comparison of serogrouping and polyacrylamide gel electrophoresis for typing. Clostridium difficile. J Clin Microbiol 1986; 24: 991-994.

4. Tabaqchali S, O'Farrell S, Holland D, Silman R. Method for typing of Clostridium difficile based on polyacrylamide gel electrophoresis of $\left[{ }^{35} \mathrm{~S}\right]$ methionine labeled proteins. $J$ Clin Microbiol 1986; 23: 197-198.

5. Sell TL, Schaberg DR, Fekety FR. Bacteriophage and bacteriocin typing scheme for Clostridium difficile. $J$ Clin Microbiol 1983; 17: 1148-1152.

6. Bowman RA, O'Neill GL, Riley TV. Non-radioactive restriction fragment length polymorphism (RFLP) typing of Clostridium difficile. FEMS Microbiol Lett 1991; 79: 269-272.

7. Delmee M, Homel M, Wauters G. Serogrouping of Clostridium difficile strains by slide agglutination. J Clin Microbiol 1985; 21: 323-327.

8. Mulligan ME, Peterson LR, Kwok RYY, Clabots CR, Gerding DN. Immunoblots and plasmid fingerprints compared with serotyping and polyacrylamide gel electrophoresis for typing Clostridium difficile. $J$ Clin Microbiol 1988; 26: 41-46.

9. Burdon DW, Brown JD, Youngs DJ et al. Antibiotic susceptibility of Clostridium difficile. J Antimicrob Chemother 1979; 5: 307-310.

10. Cartmill TD, Orr K, Freeman R, Sisson PR, Lightfoot NF. Nosocomial infection with Clostridium difficile investigated by pyrolysis mass spectrometry. $J$ Med Microbiol 1992; 37: 352356.

11. Magee JT, Brazier JS, Hosein IK et al. An investigation of a nosocomial outbreak of Clostridium difficile by pyrolysis mass spectrometry. J Med Microbiol 1993; 39: 345-351.

12. Gürtler V. Typing of Clostridium difficile strains by PCRamplification of variable length $16 \mathrm{~S}-23 \mathrm{~S}$ rDNA spacer regions. $J$ Gen Microbiol 1993; 139: 3089-3097.

13. O'Neill GL, Ogunsola FT, Brazier JS, Duerden BI. Modification of a PCR ribotyping method for application to a routine typing scheme for Clostridium difficile. Anaerobe 1996; 2: 205-209.

14. Al Saif NM, Brazier JS. The distribution of Clostridium difficile in the environment of South Wales. J Med Microbiol 1996; 45: 133-137.

15. Brazier JS. Role of the laboratory in investigations of Clostridium difficile diarrhea. Clin Infect Dis 1993; 16 Suppl 4: S228-S233.

16. Magee JT. Whole-organism fingerprinting. In: Goodfellow $M$, O'Donnell AG (eds) Handbook of new bacterial systematic. Academic Press, London. 1993: 383-427.

17. Picard B, Journet-Mancy C, Picard-Pasquier N, Goullet P. Genetic structures of the $\mathrm{B}_{2}$ and $\mathrm{B}_{1}$ Escherichia coli strains responsible for extra-intestinal infections. $J$ Gen Microbiol 1993; 139: 3079-3088.

18. Kostman JR, Edlind TD, LiPuma JJ, Stull TL. Molecular epidemiology of Pseudomonas cepacia determined by polymerase chain reaction ribotyping. J Clin Microbiol 1992; 30. 2084-2087.

19. Dolzani L, Tonin E, Lagatolla C, Monti-Bragadin C. Typing of Staphylococcus aureus by amplification of the 16S-23S rRNA intergenic spacer sequences. FEMS Microbiol Lett 1994; 119 : $167-174$.

20. O'Neill GL, Beaman MH, Riley TV. Relapse versus reinfection with Clostridium difficile. Epidemiol Infect 1991; 107: 627 635 . 